\title{
Anatomical Variability of the Infra-mammary Fold and Its Dynamics in Relation to Lejour Mammoplasty
}

\author{
Nada A. Mahmoud MD, Hesham A. Helal MD, Karim K. El-Lamei MD, \\ Abd-Al-Aziz Hanafy Abd-Al-Aziz MD.
}

\author{
Plastic Surgery Department, Ain Shams University, Cairo, Egypt.
}

Background: The anatomy and tissue components of the infra-mammary fold (IMF) have been a matter of controversy among plastic surgeons and anatomists. This clinical study was done to detect variability in IMF anatomy (position and shape), to identify factors affecting its anatomical landmarks and also the influence of Lejour reduction mammoplasty on its position.

Patients and methods: The first part of the study was done on 40 female volunteers examined clinically to define the shape and relations of the IMF to either the rib cage or the intercostal spaces. Data including age, marital status, lactation and breast volume were noted. The second part of the study included 20 cases operated on and followed up for one year after Lejour reduction mammoplasty to evaluate the effect of breast volume change on the position of the IMF.

Results: The IMF is not a straight line or a simple curve; its medial end lies between the $5^{\text {th }}$ and $7^{\text {th }}$ rib while the lateral end lies between the $5^{\text {th }}$ and $11^{\text {th }}$ rib. The IMF intersects the breast meridian at the level of the $6^{\text {th }}$ and $8^{\text {th }}$ rib. The effect of breast reduction on the IMF is quite variable, it remained in the same level in $50 \%$ and elevated in $50 \%$.

Conclusion: IMF is a dynamic structure that undergoes a downward-oriented migration and thus proper positioning and fixation of the IMF on the thoracic wall in breast reduction is a crucial step to achieve the finest results.

Key words: Inframammary fold; reduction mammoplasty; breast hypertrophy; breast reduction; breast.

\section{Introduction:}

The infra-mammary fold (IMF) is one of the most important factors in determination of aesthetics of the female breast. Being one of the 2 zones of adherence of the breast; this anatomic landmark is frequently used as a reference point in cosmetic and reconstructive breast surgeries. $^{1}$

The anatomy and tissue components of the IMF have been a matter of controversy among plastic surgeons and anatomists. Radiologically, the IMF was found opposite to the 6 th rib in most of the cases in one series. ${ }^{2}$ Some have attributed formation of the fold to a distinct ligament, 3,4 while others described a superficial fascial system. ${ }^{5,6}$ Despite this controversy; most of the plastic surgeons settled on a thought that the preservation of the integrity of the IMF is an important goal in enhancing the aesthetic result in all breast surgeries.

In aesthetic surgery of the breast it is recommended that all skin marking should be above the IMF as any skin excision or undermining that extends to the area of the IMF will lead to cut off the dermal connection to the skin with loss of the smooth curvature of the lower pole of the breast with less satisfactory results. ${ }^{7}$ In some breast reduction techniques as inferior and central pedicles the fold is not elevated, ${ }^{8}$ however in other techniques the fold is sometimes violated and elevated. ${ }^{9}$ In these situations it should be re-created again through suspension of the pectoral fascia to the dermis of the skin overlying to prevent its descent. 
This clinical study was done to detect variability in IMF anatomy (location and shape), to identify factors affecting its anatomical landmarks and also the influence of Lejour mammoplasty on its position.

\section{Patients and methods:}

This study was done between June 2011 and December 2012 in the Plastic Surgery Department, Ain Shams University. All patients signed an informed consent.

The first part of the study was done on 40 female volunteers who presented to our outpatient clinic for other procedures. Data including age, marital status, lactation and volume were noted and are summarized in (Table 1). All of them were examined clinically to define the shape and relations of the IMF to either the rib cage or the intercostals spaces at three points;

1- Point A; at the medial most point of the IMF.

2- Point $\mathrm{B}$; at the breast meridian.

3-Point $\mathrm{C}$; at the lateral most point of the IMF.

Each patient underwent bilateral mammogram with the volume of the breasts being calculated using the formula proposed by Kalbhen et al., ${ }^{10}$ because its superiority has been demonstrated in previous studies;

Breast volume $=\pi / 4 \times(\mathrm{WxHxC})$

Where $\mathrm{W}=$ breast width, $\mathrm{H}=$ breast height and $\mathrm{C}=$ compression thickness in craniocaudal mammography. The measurement was performed using a ruler on the mammography while the compression thickness was measured by the operator.

The second part of the study included 20 cases who presented to our hospital for breast reduction surgery. They all had breast reduction by superior pedicle technique described by Lejour, $1996^{11}$ operated by the same team and followed up for one year. All patients were reassessed to evaluate the effect of breast volume change on the same 3 points as in the first part of the study. Patients' demographic including age, marital status, lactation and volume are presented in Table (2).
Surgical technique:

- Pre-operatively with the patient standing marking of the sternal notch, the chest midline, the breast meridian (not necessarily crossing the nipple) and the IMF were done with the new nipple position marked according to the patients' degree of ptosis.

- Next, the standard keyhole and its arms pattern were marked to form a curve 4 cms above the inframammary fold. Then a superiorly based vertical pedicle was marked extending to $2 \mathrm{cms}$ below the nipple areola complex (NAC). Lastly, the periareolar area 4.5-5 $\mathrm{cms}$ in diameter was marked.

- Intra-operatively with patients in the supine position and the arms extended at 90 degrees; the skin on the pedicle was deepithelised. Subsequently, skin flaps were undermined and thinned starting from the lower pole followed by lower medial and finally lower lateral areas.

- At the end of undermining, the NAC was transposed to its new position and closed with $3 / 0$ and 4/0 PDS followed by suturing of a $7 \mathrm{cms}$ medial and lateral pillars using $2 / 0$ PDS interrupted sutures, then the skin flaps were closed together centrally in a $7 \mathrm{cms}$ vertical scar pattern with the whole inferior margin fixed to the pectoral fascia at the new mammary crease position through 5-6 2/0 PDS dermal suture and then the area below this point was closed with $2 / 0$ PDS pursing sutures and also fixed to the pectoral fascia. Lastly the vertical incision was closed with 3/0 PDS sutures and one suction drain was placed in each breast and removed within 3-5 days of operation.

Documentation was done by measurements with registration in the patient's file and medical photography. Breast volume was measured also by means of mammography as described former.

\section{Statistical analysis:}

Statistical presentation and analysis of the present study was conducted, using the mean, standard deviation and range for quantitative variables, unpaired student t-test to compare between two groups in quantitative data, Paired t-test used to compare between related 
sample and linear correlation coefficient tests used for detection of correlation between two quantitative variables in one group by SPSS V17, Chicago, USA; a value of $\mathrm{P}<0.05$ was considered significant.

\section{Results:}

This study was done on 60 female patients to investigate variability in the anatomical location of the IMF and in response to breast reduction surgery.

In the first part of the study, the anatomical relation of the IMF and the rib cage was assessed in 40 cases ( 80 breasts). The mean age of patients was $30.25 \pm 7.26$ (range, 19 to 48 years). Of these, 28 patients were married $(70 \%)$ and 12 were single $(30 \%)$. History of lactation was evident in 27 patients. 13 breasts were hypoplastic, 3 were average in size and 24 were hyperplastic; the mean volume of breast was $755.47 \pm 485.94$ (range, 100 to 1629.9 ).

The IMF is not always a straight line or a simple curve; its medial end lies between the $5^{\text {th }}$ and $7^{\text {th }}$ rib space while the lateral end lies between the $5^{\text {th }}$ and $11^{\text {th }}$ rib (right side) or $10^{\text {th }}$ intercostals space (left side). The IMF intersects the breast meridian at the level of the $5^{\text {th }}$ and $8^{\text {th }}$ rib Figure (1).

Regarding the effect of the demographic variants on the IMF position; only the volume of the breast was found to be independent and significant predictor for the change in the IMF position at the 3 points of study ( $\mathrm{P}$-value $\left.<0.001^{*}\right)$, while the marital status, age and lactation showed no significant difference Tables (3-5).

In the second part of the study, the variability in the anatomical location of the IMF in response to breast reduction surgery was assessed in 20 cases. The mean age of patients was $33.15 \pm 7.956$ (range, 23 to 49 years). History of lactation was evident in all patients except for 3 patients. The mean volume of breast was $1044.9 \pm 250.8$ (range, 699 to 1988). As in the first part of the study only the pre-surgical volume of the breast was found to be independent and significant predictor for the change in the IMF position at the 3 points of study Table (6).
The effect of breast reduction on the medial end of the IMF is quite variable, in all the patients the infra mammary crease was elevated in the early postoperative period however at the end of the 1 year follow-up period it retained its preoperative level in 10 cases $(50 \%)$, and stayed elevated in 10 cases $(50 \%)$. The mean pre-surgical volume of the breast which descended was 1271.68 (range, 940 to 1988), while the mean volume of those who remained at the early postoperative level was 818.05 (range, 699 to 993 ).

\section{Discussion:}

The IMF is a defining element in the shape and structure of the female breast. It is undetectable before puberty and defines the inferior extent of the breast with the onset of puberty. ${ }^{6}$ Because of its aesthetic significance, several techniques were described for recreation of the IMF after mastectomy with or without reconstruction as well as breast reduction and augmentation.

The anatomic components of the IMF have been a matter of controversy among plastic surgeons and anatomists. Blunt dissection techniques and gross observations described a ligament while histological studies did not detect any ligamentous structure in this area. Millard and Garey ${ }^{3}$ described a crescent shaped ligamentous band stretching from the anterior surface of pectoralis major muscle to the inframamary skin fold to be inserted slightly inferior to the inframamary crease. They called it the prepectoral ligament and suggested that it is responsible for the formation of the fold by supporting the breast as a sling.

Garnier et al.,2 described histologically fibres passing from the deep prepectoral fascia to the superficial fascia and did not find any connection between the superficial fascia and the dermis. Radiologically, the IMF was found opposite the $6^{\text {th }}$ rib in most of the cases. Bayati and Seckel ${ }^{4}$ carried out an anatomical study on the relation between the IMF and the underlying soft tissue structures along the rib cage. They described the inframammary crease ligament extending from the periosteum of the $5^{\text {th }}$ rib medially to 
the fascia between the $5^{\text {th }}$ and $6^{\text {th }}$ ribs laterally and inserts into the deep dermis of the IMF. They considered that this fold creates and defines the IMF and contributes to the breast shape particularly with ptosis and aging.

Muntan et al., 6 could not demonstrate ligamentous structure of dense connective tissue in their histological study. Instead, they found either fusion of the superficial $\&$ deep fascia and the dermis or fibrous insertion of the superficial fascia and the dermis at the level of the IMF. Pectoralis major, rectus abdominis and serratus anterior muscles were always present between the IMF and the rib cage.

According to Lockwood, $1991^{12}$ the topographic landmarks of the human body are largely the result of the superficial fascial system and its relationship to fat and muscle fascia. Zones of adherence of the superficial fascial system to the underlying muscle fascia or periosteum form creases of the skin whereas areas with least adherence and localized fat deposits form bulges. The upper and lateral borders are relatively mobile while the medial and lower borders are fairly fixed zones of adherence $^{13}$. Hall-Findlay, $2010^{14}$ described the breast as a subcutaneous structure having 4 footprint borders on which the breast shape is located as a third dimension. The lower border, the IMF, represents a zone of adherence, like many other areas in the body where the skin attached through fibres that prevents descent of the breast caudally. The IMF fibres are skin/fascial structures, not skin structures.

The ideal IMF is located at or above the $6^{\text {th }}$ rib but it is quite variable from person to person. ${ }^{14}$ Nava et al., 1998 stated that it is situated at $5^{\text {th }}-6^{\text {th }}$ rib with the inferior margin extending to the 6 th intercostals space. Muntan et al., ${ }^{6}$ found variability in the position of the IMF in relation to the rib cage being located superficial to the $5^{\text {th }}, 6^{\text {th }}, 7^{\text {th }}$, or $8^{\text {th }}$ rib. The medial end was mostly at the level of the $5^{\text {th }}$ or $6^{\text {th }}$ costal cartilage while the lateral extent was mostly to the level of the $7^{\text {th }}$ or 8 th rib near the anterior axillary line. At the midclavicular point below the nipple-areola, the IMF was found over the $6^{\text {th }}$ or $7^{\text {th }}$ rib. There was no predictable relationship between the inferior \& lateral borders of pectoralis major muscle and the IMF. In our study, we found that the IMF is not a straight line or a simple curve with the medial and lateral ends lying at the same level in relation to the rib cage, the lateral end tends to be lower. The lateral end of the IMF may reach a lower level than that described by Muntan et al., ${ }^{6}\left(11^{\text {th }}\right.$ versus $8^{\text {th }}$ rib).

The proper size of the breast is about $400 \mathrm{gm}$. Macromastia is considered when at least $200 \mathrm{gm}$ of tissue are removed from at least one breast during operation, i.e breast volume at least $600 \mathrm{gm} .{ }^{15}$ The breast size is an important determinant of the breast shape, the third breast dimension. ${ }^{14}$ In our study, for the determination of breast volume we have chosen mammography as it is convenient, has a considerable cost, offers a high level of accuracy and reproducibility although it is associated with poor patient tolerability. ${ }^{16}$

The incidence of noticeable breast asymmetry ranges between $4 \%$ and $10 \%$ in

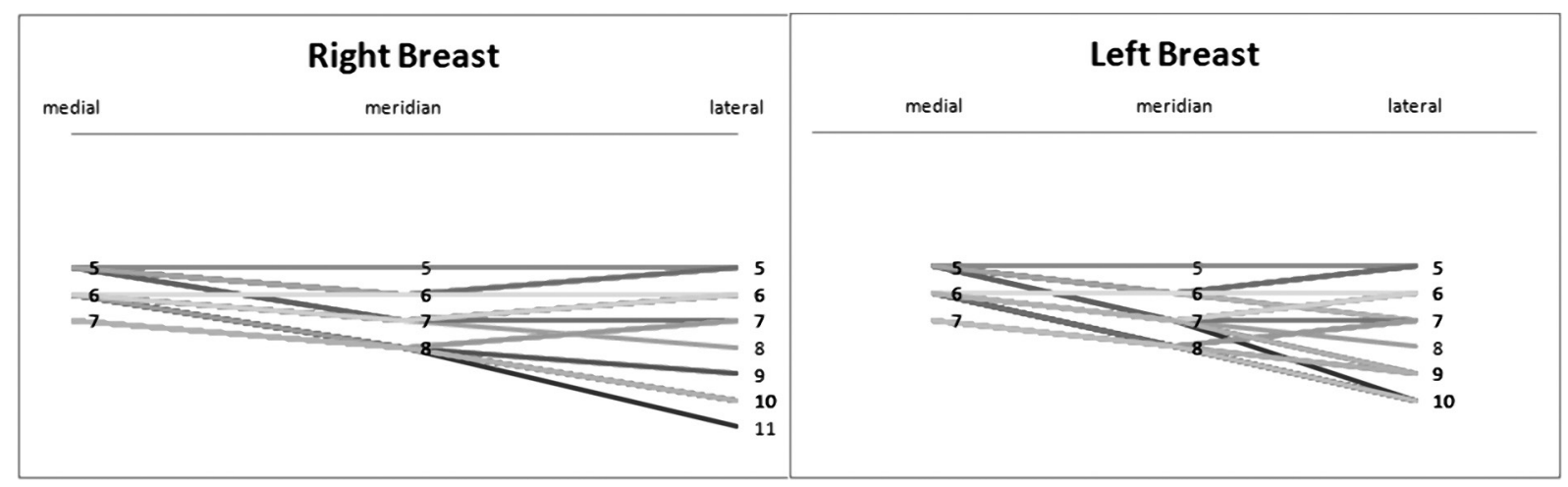

Figure (1): The shape of the IMF 
Table 1:

\begin{tabular}{|c|c|c|c|c|c|c|c|c|}
\hline \multirow{2}{*}{$\begin{array}{c}\text { Case } \\
\text { number }\end{array}$} & \multirow{2}{*}{ Age } & \multirow{2}{*}{$\begin{array}{c}\text { Marital } \\
\text { status }\end{array}$} & \multirow{2}{*}{ Lactation } & \multicolumn{4}{|c|}{ IMF } & \multirow{2}{*}{ Volume } \\
\hline & & & & & Medial & Meridian & Lateral & \\
\hline \multirow{2}{*}{1} & \multirow{2}{*}{25} & \multirow{2}{*}{ Single } & \multirow{2}{*}{ No } & Right & $7 \mathrm{r}$ & 8 & $11 \mathrm{r}$ & 1472.2 \\
\hline & & & & Left & 6 & 7 & 10 & 966.4 \\
\hline \multirow{2}{*}{2} & \multirow{2}{*}{19} & \multirow{2}{*}{ Single } & \multirow{2}{*}{ No } & Right & 5 & 6 & 5 & 837.9 \\
\hline & & & & Left & 5 & 6 & 5 & 837.9 \\
\hline \multirow{2}{*}{3} & \multirow{2}{*}{20} & \multirow{2}{*}{ Single } & \multirow{2}{*}{ No } & Right & 5 & 6 & 5 & 371.1 \\
\hline & & & & Left & 5 & 6 & 5 & 371.1 \\
\hline \multirow{2}{*}{4} & \multirow{2}{*}{32} & \multirow{2}{*}{ Married } & \multirow{2}{*}{ Yes } & Right & 5 & 7 & 6 & 145.8 \\
\hline & & & & Left & 5 & 7 & 6 & 145.8 \\
\hline \multirow{2}{*}{5} & \multirow{2}{*}{26} & \multirow{2}{*}{ Married } & & Right & 6 & $8 \mathrm{r}$ & 7 & 471.5 \\
\hline & & & Yes & Left & 6 & $8 r$ & 7 & 471.5 \\
\hline & & & & Right & 6 & $8 r$ & 9 & 873.4 \\
\hline 6 & 21 & Married & Yes & Left & 6 & $8 \mathrm{r}$ & 9 & 837.9 \\
\hline & & & & Right & $7 r$ & $8 r$ & 10 & 1423.5 \\
\hline 7 & 27 & Single & No & Left & $7 \mathrm{r}$ & $8 r$ & 10 & 1314.8 \\
\hline & & & & Right & $7 \mathrm{r}$ & $8 r$ & 10 & 953.2 \\
\hline 8 & 20 & Single & No & Left & 6 & 7 & 9 & 802.4 \\
\hline 0 & 37 & Single & No & Right & 6 & $8 \mathrm{r}$ & 9 & 1314.8 \\
\hline 9 & 31 & Single & No & Left & 6 & $8 r$ & 9 & 1314.8 \\
\hline 10 & 30 & Married & Yes & Right & 6 & $8 \mathrm{r}$ & 10 & 1503.3 \\
\hline 10 & 39 & IVarried & Yes & Left & 6 & $8 r$ & 10 & 1503.3 \\
\hline 11 & 23 & Singlo & No & Right & 5 & 7 & 6 & 651.6 \\
\hline 11 & 25 & | Dingie & 100 & Left & 5 & 7 & 6 & 651.6 \\
\hline 10 & 26 & T & V & Right & 6 & 7 & 8 & 1399 \\
\hline 12 & 26 & Married & Yes & Left & 6 & 7 & 8 & 1455.5 \\
\hline & & & & Right & 6 & 7 & 7 & 1044.1 \\
\hline 13 & 30 & Married & Yes & Left & 6 & 6 & 7 & 972 \\
\hline & & & & Right & 6 & 7 & 7 & 525.1 \\
\hline 14 & 44 & Married & Yes & Left & 6 & 6 & 6 & 376.5 \\
\hline & & & & Right & 6 & 7 & 7 & 618.3 \\
\hline 15 & 30 & Single & No & Left & 6 & 7 & 7 & 618.3 \\
\hline & 24 & & Yes & Right & 6 & $8 \mathrm{r}$ & 10 & 1416.9 \\
\hline 16 & 34 & Married & Yes & Left & 6 & $8 \mathrm{r}$ & 10 & 1563.3 \\
\hline & & & & Right & 6 & $8 r$ & 10 & 1590 \\
\hline 17 & 38 & Married & No & Left & 6 & $8 r$ & 10 & 1479.1 \\
\hline & & & & Right & 6 & 7 & 7 & 994.34 \\
\hline 18 & 48 & Married & Yes & Left & 6 & 6 & 7 & 708.15 \\
\hline 10 & 28 & Married & Yes & Right & $7 \mathrm{r}$ & $8 \mathrm{r}$ & 7 & 1629.9 \\
\hline 19 & 28 & ivarried & Yes & Left & $7 \mathrm{r}$ & $8 r$ & 7 & 1485.7 \\
\hline
\end{tabular}




\begin{tabular}{|c|c|c|c|c|c|c|c|c|}
\hline \multirow{2}{*}{$\begin{array}{c}\text { Case } \\
\text { number }\end{array}$} & \multirow{2}{*}{ Age } & \multirow{2}{*}{$\begin{array}{c}\text { Marital } \\
\text { status }\end{array}$} & \multirow{2}{*}{ Lactation } & \multicolumn{4}{|c|}{ IMF } & \multirow{2}{*}{ Volume } \\
\hline & & & & & Medial & Meridian & Lateral & \\
\hline \multirow{2}{*}{20} & \multirow{2}{*}{48} & \multirow{2}{*}{ Married } & \multirow{2}{*}{ Yes } & Right & 6 & 7 & 6 & 1361.45 \\
\hline & & & & Left & 6 & 7 & 6 & 1361.45 \\
\hline \multirow{2}{*}{21} & \multirow{2}{*}{27} & \multirow{2}{*}{ Married } & \multirow{2}{*}{ Yes } & Right & 5 & 6 & 6 & 1192.9 \\
\hline & & & & Left & 5 & 6 & 6 & 1301.6 \\
\hline \multirow{2}{*}{22} & \multirow{2}{*}{25} & \multirow{2}{*}{ Married } & \multirow{2}{*}{ Yes } & Right & 5 & 6 & 6 & 965.45 \\
\hline & & & & Left & 6 & 6 & 6 & 965.45 \\
\hline \multirow{2}{*}{23} & \multirow{2}{*}{28} & \multirow{2}{*}{ Single } & \multirow{2}{*}{ No } & Right & 5 & 6 & 6 & 525 \\
\hline & & & & Left & 5 & 6 & 6 & 971.25 \\
\hline \multirow{2}{*}{24} & \multirow{2}{*}{23} & Sinot & NI & Right & 5 & $6 r$ & 5 & 294 \\
\hline & & Singie & NO & Left & 6 & 7 & 6 & 553 \\
\hline 25 & 22 & Married & Yec & Right & 6 & 7 & 6 & 866 \\
\hline $2 J$ & | & Ivarned & res & Left & 6 & 7 & 7 & 884 \\
\hline 26 & 39 & Married & Yes & Right & $7 \mathrm{rr}$ & $8 \mathrm{r}$ & 7 & 751.3 \\
\hline 20 & 39 & IVarried & Yes & Left & $7 \mathrm{r}$ & $8 r$ & 9 & 604.9 \\
\hline 27 & 21 & Morriod & Yoc & Right & $5 r$ & 5 & $5 r$ & 100 \\
\hline 21 & | 31 & ivarmed & res & Left & $5 r$ & 5 & $5 r$ & 104 \\
\hline & & & Yec & Right & 5 & 6 & 5 & 113 \\
\hline 28 & 29 & Married & Yes & Left & 5 & 6 & 5 & 120 \\
\hline 20 & 36 & Married & Yes & Right & $6 r$ & 7 & 6 & 279 \\
\hline 29 & 30 & Ivarried & Yes & Left & $6 r$ & 7 & 6 & 308 \\
\hline 30 & 22 & Married & Yec & Right & $7 \mathrm{r}$ & $8 \mathrm{r}$ & 7 & 800 \\
\hline 30 & 32 & IVarried & Yes & Left & $7 \mathrm{r}$ & $8 r$ & 7 & 863 \\
\hline 21 & 22 & Monrind & Voc & Right & $7 \mathrm{r}$ & $8 r$ & 7 & 316 \\
\hline 31 & 23 & Married & Yes & Left & $7 \mathrm{r}$ & $8 r$ & 7 & 330 \\
\hline 22 & 26 & Singlo & No & Right & $6 r$ & 6 & $6 \mathrm{r}$ & 240 \\
\hline 32 & 20 & Single & No & Left & $6 r$ & 6 & $6 r$ & 244 \\
\hline $22+>$ & 20 & Singl & No & Right & $5 r$ & 6 & $6 r$ & 192 \\
\hline 33 & 22 & Singie & 100 & Left & $5 r$ & 6 & 6 & 409 \\
\hline 24 & 10 & Marrind & Yoc & Right & $6 r$ & 6 & $6 r$ & 273 \\
\hline 34 & | & ivarmed & res & Left & $6 r$ & 6 & $6 r$ & 287 \\
\hline 35 & 26 & Married & Yes & Right & $6 r$ & 6 & $6 r$ & 139 \\
\hline 35 & 20 & IVarried & Yes & Left & $6 r$ & 6 & $6 r$ & 132 \\
\hline 36 & 32 & Married & Yes & Right & $6 r$ & 6 & 6 & 130 \\
\hline 30 & 32 & Ivarmed & res & Left & $6 r$ & 6 & 6 & 144 \\
\hline 27 & 20 & Momind & Vor & Right & 6 & 7 & 6 & 106 \\
\hline 31 & 28 & IVarried & Yes & Left & 6 & 7 & 6 & 106 \\
\hline & & & & Right & $6 r$ & 7 & 6 & 200 \\
\hline 38 & 30 & Married & Yes & Left & $6 r$ & 7 & 6 & 200 \\
\hline 30 & 20 & & $V_{0}$ & Right & $7 \mathrm{r}$ & $8 r$ & 10 & 1324 \\
\hline 39 & 30 & Ma1 & Yes & Left & $7 \mathrm{r}$ & $8 r$ & 10 & 1314 \\
\hline
\end{tabular}




\begin{tabular}{|c|c|c|c|c|c|c|c|c|}
\hline \multirow{2}{*}{$\begin{array}{c}\text { Case } \\
\text { number }\end{array}$} & \multirow{2}{*}{ Age } & \multirow{2}{*}{$\begin{array}{c}\text { Marital } \\
\text { status }\end{array}$} & \multirow{2}{*}{ Lactation } & \multicolumn{4}{|c|}{ IMF } & \multirow{2}{*}{ Volume } \\
\hline & & & & & Medial & Meridian & Lateral & \\
\hline \multirow{2}{*}{40} & \multirow{2}{*}{36} & \multirow{2}{*}{ Married } & \multirow{2}{*}{ Yes } & Right & $7 \mathrm{r}$ & $8 \mathrm{r}$ & 10 & 1053 \\
\hline & & & & Left & 6 & 7 & 9 & 902 \\
\hline
\end{tabular}

(*) r= rib

Table 2: Patients'data:

\begin{tabular}{|c|c|c|c|c|c|c|c|c|c|c|c|c|}
\hline \multirow{2}{*}{ 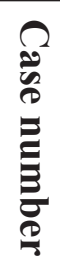 } & \multirow[b]{2}{*}{$\underset{\theta}{\overrightarrow{0}}$} & \multirow[b]{2}{*}{ 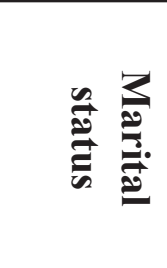 } & \multirow[b]{2}{*}{ 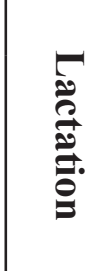 } & \multicolumn{4}{|c|}{ IMF (pre-operative) } & \multirow[b]{2}{*}{ 冚 } & \multicolumn{4}{|c|}{ IMF (post-operative) } \\
\hline & & & & & 疋 & 高: & $\frac{9}{20}$ & & & 光 & 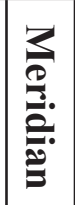 & $\frac{}{\frac{0}{2}}$ \\
\hline \multirow[t]{2}{*}{1} & \multirow[t]{2}{*}{28} & \multirow[t]{2}{*}{ Married } & \multirow[t]{2}{*}{ Yes } & Right & $7 \mathrm{r}$ & 8 & 10 & 1429.9 & Right & $7 \mathrm{r}$ & 8 & 10 \\
\hline & & & & Left & $7 \mathrm{r}$ & 7 & 10 & 1385.7 & Left & $7 \mathrm{r}$ & 7 & 10 \\
\hline \multirow[t]{2}{*}{2} & \multirow[t]{2}{*}{28} & \multirow[t]{2}{*}{ Married } & \multirow[t]{2}{*}{ Yes } & Right & $7 \mathrm{r}$ & 8 & 7 & 940 & Right & $7 \mathrm{r}$ & 8 & 7 \\
\hline & & & & Left & $7 \mathrm{r}$ & 8 & 9 & 940 & Left & $7 \mathrm{r}$ & 8 & 9 \\
\hline \multirow[t]{2}{*}{3} & \multirow[t]{2}{*}{38} & \multirow[t]{2}{*}{ Married } & \multirow[t]{2}{*}{ Yes } & Right & $7 \mathrm{r}$ & 8 & 9 & 980 & Right & $7 \mathrm{r}$ & 8 & 9 \\
\hline & & & & Left & $7 \mathrm{r}$ & 8 & 9 & 980 & Left & $7 \mathrm{r}$ & 8 & 9 \\
\hline \multirow[t]{2}{*}{4} & \multirow[t]{2}{*}{45} & \multirow[t]{2}{*}{ Married } & \multirow[t]{2}{*}{ Yes } & Right & $7 \mathrm{r}$ & 8 & 10 & 1370 & Right & $7 \mathrm{r}$ & 8 & 10 \\
\hline & & & & Left & $7 \mathrm{r}$ & 8 & 10 & 1370 & Left & $7 \mathrm{r}$ & 8 & 10 \\
\hline \multirow[t]{2}{*}{5} & \multirow[t]{2}{*}{26} & \multirow[t]{2}{*}{ Married } & \multirow[t]{2}{*}{ Yes } & Right & $7 \mathrm{r}$ & 8 & 10 & 1539 & Right & $7 \mathrm{r}$ & 8 & 10 \\
\hline & & & & Left & $7 \mathrm{r}$ & 8 & 10 & 1532 & Left & $7 \mathrm{r}$ & 8 & 10 \\
\hline 6 & 23 & Single & No & Right & $7 \mathrm{r}$ & 7 & 7 & 857 & Right & 5 & 6 & 6 \\
\hline & & & & Left & $7 \mathrm{r}$ & 7 & 7 & 857 & Left & 6 & 6 & 6 \\
\hline 7 & 34 & Married & Yes & Right & $7 \mathrm{r}$ & 8 & 7 & 1988 & Right & $7 \mathrm{r}$ & 8 & 7 \\
\hline & & & & Left & $7 \mathrm{r}$ & 8 & 7 & 1988 & Left & $7 \mathrm{r}$ & 8 & 7 \\
\hline 8 & 28 & Married & Yes & Right & 6 & 7 & 7 & 816 & Right & 5 & 6 & 6 \\
\hline & & & & Left & 6 & 6 & 7 & 816 & Left & 5 & 6 & 6 \\
\hline 9 & 29 & Married & Yes & Right & $7 \mathrm{r}$ & 8 & 10 & 1024 & Right & $7 \mathrm{r}$ & 8 & 10 \\
\hline & & & & Left & $7 \mathrm{r}$ & 7 & 9 & 1150 & Left & $7 \mathrm{r}$ & 7 & 9 \\
\hline 10 & 37 & Married & Yes & Right & $6 r$ & 7 & 6 & 807 & Right & 5 & 6 & 5 \\
\hline & & & & Left & 6 & 7 & 6 & 807 & Left & 5 & 6 & 5 \\
\hline 11 & 49 & Married & Yes & Right & $7 \mathrm{r}$ & 7 & 8 & 1300 & Right & $7 \mathrm{r}$ & 7 & 8 \\
\hline & & & & Left & $7 \mathrm{r}$ & 7 & 8 & 1500 & Left & $7 \mathrm{r}$ & 7 & 8 \\
\hline 12 & 30 & Married & Yes & Right & 6 & 7 & 7 & 770 & Right & 5 & 6 & 6 \\
\hline & & & & Left & 6 & 6 & 7 & 770 & Left & 5 & 6 & 6 \\
\hline 13 & 26 & Single & No & Right & 5 & 7 & 6 & 777 & Right & 5 & 6 & 5 \\
\hline & & & & Left & $5 r$ & 7 & 6 & 770 & Left & 5 & 6 & 5 \\
\hline 14 & 37 & Married & Yes & Right & 6 & 7 & 7 & 704 & Right & 5 & 6 & 5 \\
\hline & & & & Left & 6 & 6 & 6 & 704 & Left & 5 & 6 & 5 \\
\hline 15 & 32 & Married & Yes & Right & $6 r$ & 7 & 6 & 993 & Right & 5 & 6 & 6 \\
\hline & & & & Left & 6 & 7 & 6 & 910 & Left & 5 & 6 & 6 \\
\hline
\end{tabular}




\begin{tabular}{|c|c|c|c|c|c|c|c|c|c|c|c|c|}
\hline \multirow{2}{*}{ 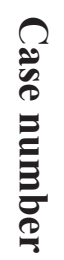 } & \multirow[b]{2}{*}{$\overrightarrow{r o g}$} & \multirow[b]{2}{*}{ 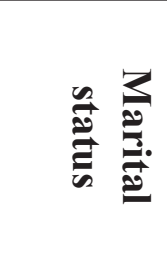 } & \multirow[b]{2}{*}{ 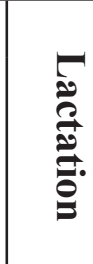 } & \multicolumn{4}{|c|}{ IMF (pre-operative) } & \multirow[b]{2}{*}{ 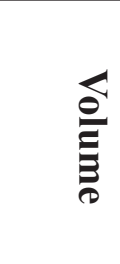 } & \multicolumn{4}{|c|}{ IMF (post-operative) } \\
\hline & & & & & 客 & 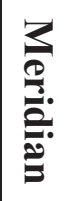 & $\frac{2}{30}$ & & & 这. & :3.0. & 营 \\
\hline \multirow[t]{2}{*}{16} & \multirow[t]{2}{*}{39} & \multirow[t]{2}{*}{ Married } & \multirow[t]{2}{*}{ Yes } & Right & 6 & 7 & 6 & 880 & Right & 5 & 6 & 5 \\
\hline & & & & Left & 6 & 7 & 6 & 863 & Left & 5 & 6 & 5 \\
\hline \multirow[t]{2}{*}{17} & \multirow[t]{2}{*}{41} & \multirow[t]{2}{*}{ Married } & \multirow[t]{2}{*}{ Yes } & Right & $6 r$ & 7 & 6 & 931 & Right & 5 & 6 & 6 \\
\hline & & & & Left & 6 & 7 & 7 & 931 & Left & 5 & 6 & 6 \\
\hline \multirow[t]{2}{*}{18} & \multirow[t]{2}{*}{44} & \multirow[t]{2}{*}{ Married } & \multirow[t]{2}{*}{ Yes } & Right & $7 \mathrm{r}$ & 8 & 10 & 972 & Right & $7 \mathrm{r}$ & 8 & 10 \\
\hline & & & & Left & $7 \mathrm{r}$ & 7 & 9 & 983 & Left & $7 \mathrm{r}$ & 7 & 9 \\
\hline \multirow[t]{2}{*}{19} & \multirow[t]{2}{*}{25} & \multirow[t]{2}{*}{ Married } & \multirow[t]{2}{*}{ Yes } & Right & 6 & 7 & 7 & 699 & Right & 5 & 6 & 6 \\
\hline & & & & Left & 6 & 7 & 7 & 699 & Left & 5 & 6 & 6 \\
\hline \multirow[t]{2}{*}{20} & \multirow[t]{2}{*}{24} & \multirow[t]{2}{*}{ Single } & \multirow[t]{2}{*}{ No } & Right & $7 \mathrm{r}$ & 8 & 7 & 1030 & Right & $7 r$ & 8 & 7 \\
\hline & & & & Left & $7 \mathrm{r}$ & 8 & 7 & 1032 & Left & $7 r$ & 8 & 7 \\
\hline
\end{tabular}

Table 3: Shows no significant differences concerning the marital status in relation to the variation of IMF location.

\begin{tabular}{|c|c|c|c|c|c|c|c|c|}
\hline & \multicolumn{8}{|c|}{ Marital status } \\
\hline & \multicolumn{3}{|c|}{ Single } & \multicolumn{3}{|c|}{ Married } & \multicolumn{2}{|c|}{ T-test } \\
\hline & Mean & \pm & SD & Mean & \pm & SD & $\mathbf{T}$ & P-value \\
\hline \multicolumn{9}{|c|}{ Right } \\
\hline Medial & 5.75 & \pm & 0.87 & 6.04 & \pm & 0.64 & -1.165 & 0.251 \\
\hline Meridian & 6.83 & \pm & 0.94 & 7.11 & \pm & 0.88 & -0.888 & 0.380 \\
\hline Lateral & 7.17 & \pm & 2.21 & 7.11 & \pm & 1.59 & 0.096 & 0.924 \\
\hline \multicolumn{9}{|c|}{ Left } \\
\hline Medial & 5.67 & \pm & 0.65 & 6.04 & \pm & 0.58 & -1.786 & 0.082 \\
\hline Meridian & 6.75 & \pm & 0.75 & 6.96 & \pm & 0.92 & -0.708 & 0.483 \\
\hline Lateral & 7.08 & \pm & 1.88 & 7.14 & \pm & 1.58 & -0.103 & 0.918 \\
\hline
\end{tabular}

Table 4: Shows no significant differences concerning lactation in relation to the variation of IMF location.

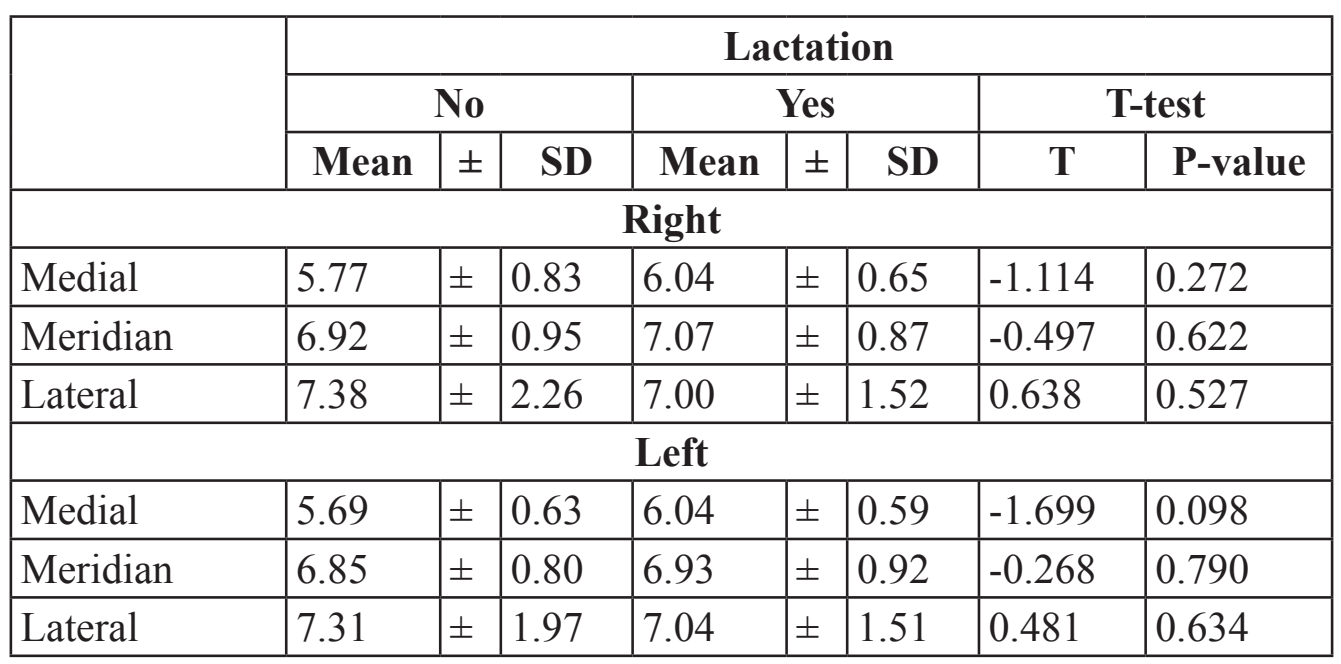


Table 5: Shows no significant differences concerning age of the patient in relation to the variation of IMF location and also shows that the volume of the breast was found to be independent and significant predictor for the change in the IMF position at the 3 points of study (P-value $<0.001$ *).

\begin{tabular}{|l|l|l|l|l|}
\hline \multirow{2}{*}{} & \multicolumn{2}{c|}{ Age } & \multicolumn{2}{c|}{ Volume } \\
\cline { 2 - 5 } & \multicolumn{1}{|c|}{ R } & \multicolumn{1}{c|}{ P-value } & R & P-value \\
\hline \multicolumn{5}{|c|}{ Right } \\
\hline Medial & 0.204 & 0.207 & 0.516 & $<0.001^{*}$ \\
\hline Meridian & 0.180 & 0.266 & 0.609 & $<0.001^{*}$ \\
\hline Lateral & 0.126 & 0.437 & 0.717 & $<0.001^{*}$ \\
\hline \multicolumn{5}{|c|}{ Left } \\
\hline Medial & 0.221 & 0.170 & 0.410 & $0.009^{*}$ \\
\hline Meridian & 0.069 & 0.674 & 0.499 & $<0.001^{*}$ \\
\hline Lateral & 0.153 & 0.347 & 0.657 & $<0.001^{*}$ \\
\hline
\end{tabular}

Table 6: Shows that only the pre-surgical volume was found to be independent and significant predictor for the change in the IMF position at the 3 points of study (P-value $<0.001 *)$.

\begin{tabular}{|c|c|c|}
\hline \multirow[b]{2}{*}{ Right } & \multicolumn{2}{|c|}{ Volume } \\
\hline & $\mathbf{r}$ & P-value \\
\hline Medial pre & 0.645 & $0.002 *$ \\
\hline Meridian pre & 0.515 & $0.020^{*}$ \\
\hline Lateral pre & 0.650 & $0.002 *$ \\
\hline Medial post & 0.224 & 0.342 \\
\hline Meridian post & -0.051 & 0.831 \\
\hline Lateral post & -0.013 & 0.956 \\
\hline \multicolumn{3}{|l|}{ Left } \\
\hline Medial pre & 0.673 & $0.003 *$ \\
\hline Meridian pre & 0.751 & $0.004 *$ \\
\hline Lateral pre & 0.544 & $0.013^{*}$ \\
\hline Medial post & 0.212 & 0.369 \\
\hline Meridian post & 0.045 & 0.851 \\
\hline Lateral post & 0.109 & 0.649 \\
\hline
\end{tabular}

the literature. ${ }^{17}$ Our study showed that more than half of the female-population is affected by minor degrees of asymmetry. Asymmetry was not the presenting complaint probably because only major variations may present significant physical, social, and psychological concern. ${ }^{18}$

Great variability was observed in the three reference points of the IMF; this variability correlates with breast volume, pregnancy and lactation, probably due to laxity and stretch of the fold of the superficial fascial system although some authors stated that breastfeeding does not worsen breast ptosis. ${ }^{19}$ In our study, variability of the IMF is more pronounced at the lateral end (point c), that reached the $9^{\text {th }}$ - $11^{\text {th }}$ rib in 21 out of 80 hyperplastic breasts (26.2\%).

According to Hall-Findlay, 2010, ${ }^{14}$ an implant tends to lower the IMF even without 
violation of its fibres. Breast reduction leaving the weight of the remaining breast tissue inferiorly or compression of the breast tissue by tight skin brassier closure also lowers the IMF. It can be elevated by removing breast tissue above the fold from the lower part of the breast as in superior or superomedial pedicle techniques or by liposuction In our study, reduction mammaplasty by the superior pedicle technique tends to elevate or at least preserve the level of the IMF in $50 \%$ of cases after a period of 1 year. This is due to resection of the lower part of the breast parenchyma which tends to gravitates inferiorly with the inferior pedicle technique, 11,20 and so we recommend that the patients be informed about this probability of IMF descent in addition to the usual complications of reduction mammoplasty.

The mean pre-surgical volume of the breasts with elevated IMF (818.05) was much less than the breast that retained the pre-surgical level (1271.68) and so to avoid this bottoming out we recommend that more elevation of the IMF $(>4 \mathrm{cms})$ with extra fixation at the new level should be done in breasts with high mean pre-operative volume $(>820)$. We think that more studies with larger number of patients are needed to detect the critical pre-operative volume at which postoperative IMF descent might occur.

\section{Reference:}

1- Chun YS, Pribaz JJ: A simple guide to inframammary-fold reconstruction. Ann Plast Surg 2005; 55: 8-11.

2- Garnier D, Angonin R, Foulan R, et al: Le sillon sous-mammaire: Mythe ou realite? Ann Chir Plast Esthet 1991; 36: 313. Quoted after Muntan et al, 2000.

3- Millard GF, Garey IJ: An improved technique for immediate retropectoral reconstruction after subcutaneous mastectomy. Plast Reconstr Surg 1987; 80: 396.

4- Bayati S, Seckel BR: Inframammary crease ligament. Plast Reconstr Surg 1995; 95: 501-508.

5- Nava M, Quattone P, Riggio E: Focus on the breast fascial system: A new approach for inframammary fold reconstruction. Plast Reconstr Surg 1998; 102: 1034-1045.

6- Muntan CD, Sundine MJ, Rink RD, Acland
RD: Inframammary fold: A histologic reappraisal. Plast Reconstr Surg 2000; 105: 549-556.

7- Boutros S, Kattash M, Wienfeld A, Yuksel E, Baer S, Shenaq S: The intradermal anatomy of the inframammary fold. Plast Reconstr Surg 1998;102(4): 1030-1033.

8- Lassus C: A technique for breast reduction. Int Surg. 1970; 53: 69-72.

9- Hall-Findlay EJ: Vertical breast reduction with a medially based pedicle: Operative strategies. Aesthet Surg J 2002; 22: 185-195.

10- Kalbhen CL, McGill J, Fendley PM, Corrigan KW, Angelats J: Mammographic determination of breast volume: Comparing different methods. Am J Roentgenol 1999; 173: $1643-1649$.

11- Lejour M: Vertical mammaplasty for breast hypertyrophy and ptosis. Op Tech Plast Reconst Surg 1996; 3: 189.

12- Lockwood TE: Superficial fascial system (SFS) of the trunk and extremities: A new concept. Plast reconstr Surg 1991; 87: 1009-1018.

13- Rohrich RJ, Smith PD, Marcantonio DR, et al: The zones of adherence: Role in minimizing and preventing contour deformities during liposuction. Plast Reconstr Surg 2001; 107 : 1562-1569.

14- Hall-Findlay E: The three breast dimensions: Analysis and effecting change. Plast Reconstr Surg 2010; 125: 1632-1642.

15- Strombeck JO: Macromastia in women and its surgical correction. Acta Chir Scand Suppl 1964; 3431:1. Quoted after: Davis GM, Ringler SL, Short K, Sherrick D, Bengtson BP: Reduction mammaplasty: Long-term efficacy, morbidity and patient satisfaction. Plast Reconstr Surg 1995; 96: 1106.

16- Kayar R, Civelek S, Cobanoglu M, Gungor $\mathrm{O}$, Catal H, Emiroglu M: Five methods of breast volume measurement: A comparative study of measurements of specimen volume in 30 mastectomy cases. Breast Cancer (Auckl) 2011; 27(5): 43-52.

17- Pitanguy I: Amastia and mammary asymmetries. The International microform Journal of Aesthetic Plastic Surgery. Transactions of the $2^{\text {nd }}$ congress of the International Society of Aesthetic Plastic Surgery, 1974-D. Quoted after: Aston SJ, Rees TD: Mammary augmentation, correction of asymmetry and gynecomastia. In: Rees TD. (Editor), Aesthetic Plastic Surgery. W.B. Saunders Company. Philadelphia- LondonToronto. Chapter 34. P 954, 1980. 
18- Hoehn JG, Georgiade GS, Georgiade NG: Congenital and developmental deformities of the breast. In: Georgiade GS, Georgiade NG, Riefkohl R, Barwick WJ. (Editors). Text book of plastic, maxillofacial and reconstructive surgery. Williams Wilkins. Baltimore- Hong Kong -London- Munich- PhiladelphiaSydney- Tokyo. Second edition. Chapter 60. P 783, 1992.

19- Rinker B, Veneracion M, Walsh CP: The effect of breastfeeding on breast aesthetics. Aesthet Surg J 2008; 28(5): 534-537.

20- White DJ, Maxwell GP: Breast reduction. In: Achauer BM, Eriksson E, Guyuron B, Coleman III JJ, Russell RC, Vander Kolk CA. (Editors). Plastic surgery; Indications, operations, and outcomes. St. Louis . London. Philadelphia . Sydney . Toronto., Mosby, Inc., 2000, Volume V, Chapter 149, p 2705. 


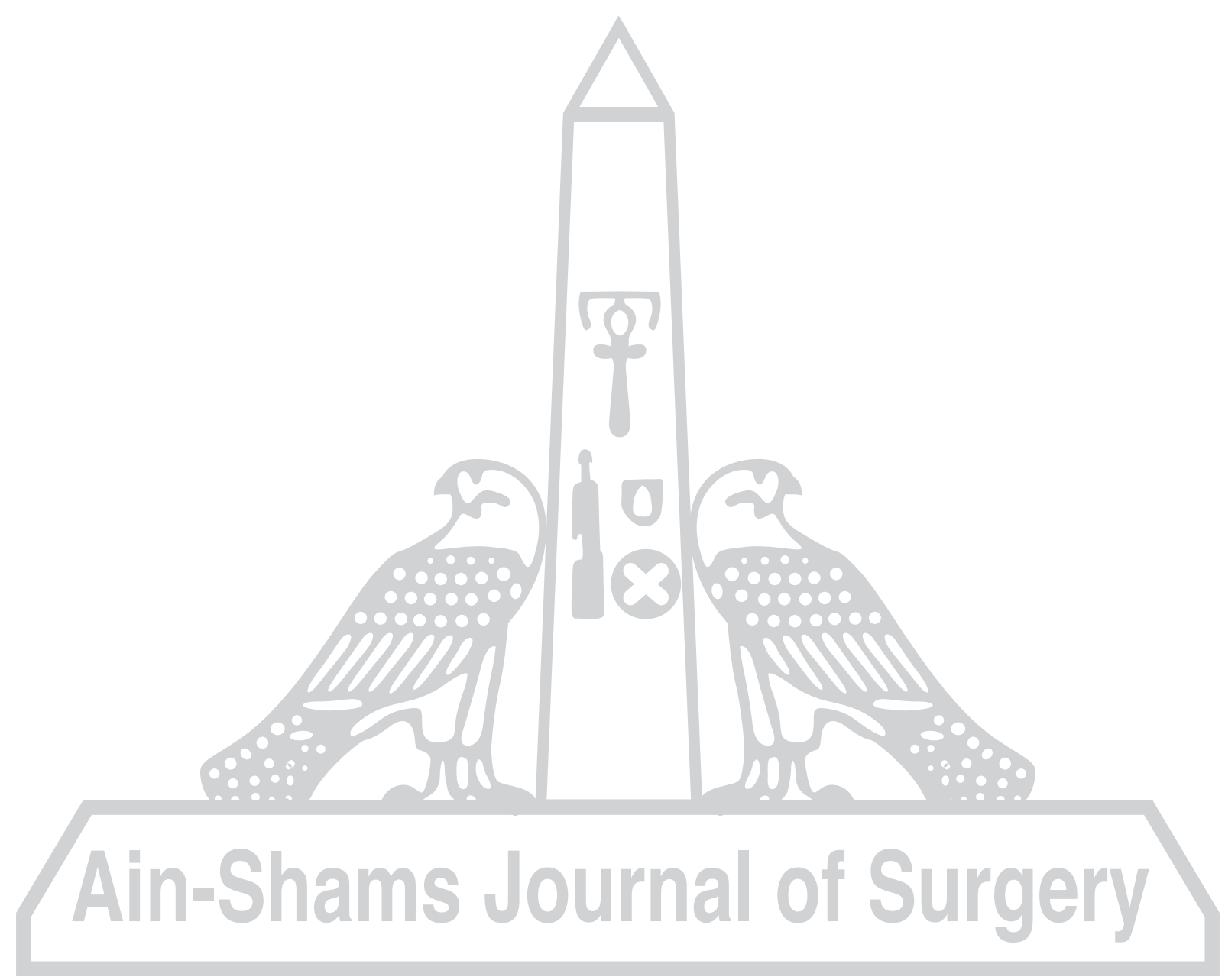

